\title{
Confined in Waiting - Young Asylum Seekers Narrating In and Out of Temporary Shelter
}

To cite this article: Petäjäniemi, M., Kaukko, M \& Lanas, M. (2021). Confined in Waiting - Young Asylum Seekers Narrating In and Out of Temporary Shelter. Young, 29(1), 62-80.

\begin{abstract}
This research considers the waiting and confinement experienced by young asylum seekers during and after their stay at a temporary shelter in Finland. The data for this research consists of interviews and ethnographic 'hanging out' with nine young asylum seekers throughout their asylum process. In order to generate new knowledge about the situated and fluid experiences of young adult asylum seekers' confinement, this paper focuses on four in-depth interviews with two young men, Kokab and Mahammed. They arrived in Finland in 2015, and are, at the time of writing this article, still waiting for their final asylum decisions. The results show, firstly, that while the time in the temporary shelter resembles physical, punitive confinement, it is also experienced as warm and social time. Secondly, the article argues that the confinement of young asylum seekers extends beyond the physical confinement, as they are for years confined in forced movement, indefinite waiting, and othered as a number in the system.
\end{abstract}

Keywords: Confinement, waiting, asylum seeker, temporary shelter, narrative/post-qualitative inquiry

\section{Introduction}

The confinement of children, youth and young adults can have detrimental effects on their health and wellbeing. Young adult asylum seekers in the focus of this research, must deal with an additional burden of losing their already gained independence as they enter an institutionalized life in their new countries. While young adult asylum seekers may have the physique and life experiences of an adult, their position in the society resembles that of children - they are waiting for their permission to partake in the society as a full member. This means that much of what we think we know about youth and young adulthood as particular stages in life must be rethought when the group in focus have refugee and asylum-seeking backgrounds.

At present, over 65 million people have been forced to move from their homes and seek asylum. This figure includes internally (i.e. forced to move within national borders) and internationally displaced persons, many of whom will end up confined in countries of transit or destination. (United Nations High Commissioner for Refugees [UNHCR], 2018). There is a small but growing body of literature looking at confinement from the point of view of young migrants (Martin \& Mitchelson, 2009; Mountz, Coddington, Catania, \& Loyd, 2012; Chase 2013). This article adds to this body of literature by investigating the phase of life in which asylum-seeking young people are between temporary shelters and 'real life' in the Finnish society. In particular, this paper considers this phase of asylum 
seekers' lives longitudinally, elaborating on how the lives of young asylum seekers unfold during their confinement.

During the so-called refugee crisis ${ }^{1}$ in 2015 , the number of asylum seekers arriving in Finland increased tenfold within a single year ${ }^{2}$. In ordinary situations, asylum seekers arriving in Finland are first placed in transit centres, where they wait for their first asylum interview. After that, they are transferred to a reception centre to wait for a decision. In 2015, reception centres across Finland filled up, and temporary shelters were established. Temporary shelters were maintained by the Finnish Immigration Service, municipalities, NGOs and companies, and they offered the same services and operated according to the same principles like the permanent reception centres. All of these institutions differ in their level of freedom and confinement: some can have locked doors and bars on the windows, whereas others are homelike institutions that allow residents to move freely.

The temporary shelters were commonly characterized by relatively low standards of living and were often located in former institutional buildings, such as schools, hospitals and other leftover property. While the aim of these institutions was to provide care and temporary housing for asylum seekers, the way they confined asylum seekers was largely viewed as punitive (due to, for example, predetermined routines, the lack of space, or remote locations) (see e.g. Nykänen, Koikkalainen, Seppälä, Mikkonen, \& Rainio, 2019). The residents, most of whom were young adults, expressed gratitude for the protection and care, but many also reported feelings of isolation from society at large (Petäjäniemi, Lanas, \& Kaukko, 2018).

While the recent demographic changes have intensified research interest focusing on the lives of young asylum seekers and refugees in Finland and Europe (i.e. Koser, 2016; Lems, Oester \& Strasser, 2019; Kohli \& Kaukko, 2018; Honkasalo, et al., 2017), more research is needed with its main focus on how waiting and confinement unfold in the lives of young asylum-seeking adults in this precarious situation. As the majority of asylum seekers are youth or young adults ${ }^{3}$, the need to understand temporary shelters as sites of youth confinement is significant. In this study, we are interested in the experiences of young adults over the age of 18. Under-aged asylum seekers, both accompanied and unaccompanied, are accommodated in other forms of housing (e.g. Honkasalo, et al., 2017).

The research followed the lives of nine young asylum-seeking men in 2015-2018. During that time, the men lived in a temporary shelter in Northern Finland for one year, followed by two years in rental apartments. Data was generated through ethnographic hanging out (see also Pyyry, 2015; Tani, 2014) and interviews with the participants. For the sake of particular and in-depth knowledge, we decided in this article to focus on the stories of two young asylum seekers, Kokab and Mahammed (selfchosen pseudonyms), aged 27 and 31, both of whom are still, in the end of the year 2019, waiting for their final asylum decisions. Through two sets of in-depth interviews conducted in 2016 and 2018, we look at how the everyday lives of Kokab and Mahammed have unfolded throughout their changing

\footnotetext{
${ }^{1}$ Like Perre, De Vries, Richards and Gkliati (2018), we consider the events leading to the increase in forced migration in 2015 to be a crisis of protection, solidarity and humanity rather than a refugee crisis.

${ }^{2}$ In 21 st century the number of asylum applications in Finland has changed between 1 500-6 000. In 2015, the number went up to 32476 . In 2018, the situation reverted and 4548 people sought for international protection from Finland. (Finnish Immigration Service 2019).

${ }^{3}$ In $2015,60,3 \%$ of the people seeking asylum from Finland were 18-34 years old (Finnish Immigration Service 2019).
} 
situations in and out of the temporary shelter and more ordinary dwellings. We also look at how they narrate their experiences of waiting and confinement during and after their stays at the temporary shelter.

\section{Being confined to the position of a 'seeker'}

Martin and Mitchelson (2009) define confinement or detention as the use of incarceration by states to contain people who may or may not be charged with crimes. Asylum seekers, refugees, children without guardians, people suffering from mental illnesses, terrorism suspects, political dissidents and others may be confined without committing a crime due to uncertain citizenship or visa status, ongoing legal proceedings, protections and likelihood of committing a violent act. Confinement does not necessarily mean that people are locked in institutions. Instead, to confine is to "keep or restrict someone or something within certain limits of space, scope, or time" (Oxford Dictionaries, 2019). Many who are confined lack the legal ability to claim rights, which means that detainees may be invisible and politically silenced (Martin \& Mitchelson, 2009). Losing control of certain aspects of everyday lives may amplify the feeling of being "trapped", even if people would not be fully and literally confined (Fontanari, 2015). People whose freedom is limited may be perceived as potentially dangerous by the local community, which in turn may be experienced by the confined people as more or less explicit hostility (Campesi, 2015).

Individuals waiting for an asylum decision are confined in the present, awaiting a future they may not imagine and cannot reach (Brun, 2015). Asylum seekers wait for acceptance, which grants permission to begin a new stage of their lives. Sometimes they wait for years ${ }^{4}$, and sometimes, in areas of prolonged conflict, for their whole lifetimes. As Schweizer (2008, p. 2) states, 'to wait is to have time without wanting it'. Waiting in the context of forced migration is often seen as passive and empty time (e.g. Rotter, 2016), as if asylum seekers' lives were on pause. As Kohli and Kaukko (2018, p. 489) argue, waiting for young asylum seekers means that 'the clock ticks, but no movement happens'. Involuntary waiting confines young people who have their lives ahead of them, into a liminal stage of life with little experienced purpose; into being 'betwixt and between', detached from an old status but not yet incorporated into a new one (Malkki 1995; Turner 1964). Before the asylum decision, the asylum seekers cannot fully arrive in the country; they are kept on hold, in a state of 'arrival-inbetween' (Thorshaug, 2018, p. 207). In effect, they regress to the position of minors, waiting to become actual members of society.

Reception centres act as socio-spatial formations that restrict aspects of individuals' mobility and serve as threshold places in which subjects are confined (Fontanari, 2015). In other words, although the individuals are allowed physical mobility to a certain extent, they are confined as subjects. This means that their lives, identities and possibilities are confined due to their status as asylum seekers; they are confined to the position of 'seeker' until an external decision is made, which would allow them to move on to other positions in the society and in their lives. Asylum seekers live on the threshold of their futures and must prepare themselves for at least two opposing outcomes: settling in the new country or returning to their country of origin. Waiting in these societal, spatial and

\footnotetext{
${ }^{4}$ There are no statistics available for how long in average asylum seekers wait for their first decisions on their applications in Finland. According to the estimation of the Finnish Immigration Service, the time for the asylum seekers who left their applications in 2017, would be 16-20 months. (Yle 2018.)
} 
ontological thresholds is meant to be temporary; these spaces are meant to serve as a gateway allowing asylum seekers to move on in times of crisis. Agamben (1998, p. 168) writes about refugee camps using language that applies to other shelters, too: 'the camp is the space that opens up when the state of exception starts to become the rule'; normalizing the exception leads to 'permanent temporariness' (Bailey, Wright, Mountz, \& Miyares, 2002, p. 138).

A strong counterargument against the above views, originating especially from the feminist branches of refugee studies, claims that seeing places such as temporary shelters or reception centres simply as spaces of exclusion is an overly universal view that overlooks the experiences of the people living in them (e.g., Abourahme, 2014; Mountz, 2011; Sharma, 2009). Similar claims have been made in youth research: young people have creative ways of navigating in spaces that limit their freedom (e.g. Allsopp, et al., 2015; Enell 2017; Kaukko \& Parkkila 2014). Even in confined places, everyday rituals, such as cooking and eating together can be comforting. Such activities can create breaks in the temporality of waiting and uncertainty; they may create opportunities for asylum seekers to have some control over their lives, and connect with others in similar situations. A shared experience of waiting can build a sense of communality and relatedness, and thus create a temporary sense of certainty (Verdasco, 2019). Time spent in these spaces can be active and even productive (Rotter, 2016), as the spaces become sites of everyday life. Social networks and affiliations in reception centres can provide an alternative support mechanism in circumstances marked by public hostility, precarious entitlement and conditional rights (Sigona, 2015). At best, these institutions can offer newcomers some practical benefits, care and social participation (Petäjäniemi, Lanas, \& Kaukko, 2018), although these may be overshadowed by the experience of punitive confinement.

The research at hand aims to illuminate the dimensions of confinement that arise from the research participants' everyday lives and from the meanings they attach to confinement. As we detail below, our study examines both the restricting and confining as well as the warm and positive aspects of life in and after a temporary shelter.

\section{The research}

The research is grounded in ethnographic "hanging out". Such hanging out had no schedules or structure (Pyyry, 2015; Tani, 2014), and it took place in the public and private spaces in which the participants spent time. Here, the ethnographic 'field' is not seen as a place for the researcher to enter and to leave, but more nomadically, as something that becomes built organically together with participants and that is constantly in motion. This enabled formulating the research so that it was open to the unexpected, and could capture something of the lived experience of the young asylum seekers' time of waiting. The first author spent time with the participants at their homes as well as in public places. Later, she was invited to birthdays, weddings and other meaningful events. She became a part of the field, as is common in this kind of ethnographic research, and she did not pursue to leave the field after the research-period was over (for ethics of leaving see e.g. Duncombe \& Jessop, 2002; Heyl, 2007; Murphy \& Dingwall, 2007; Stacey 1988). This was seen as ethically important when working with youth or young adults in vulnerable situations (see Kaukko, Korkiamäki \& Kuusisto, 2019). 
The research began in a temporary shelter in Northern Finland in 2015 and followed the lives of nine young asylum seekers throughout a period of three years. The shelter closed in the summer of 2016, after which eight participants moved to rental apartments and one participant voluntarily returned to his country of origin. At the beginning of 2019, two of the participants has received a four-year residency permits, while the others are still waiting. The positions of the people involved in this kind of research are continually rethought (Cole, 2013; Ikävalko, 2016), as a research relationship is not something established once, but it is something constantly 'done' (Lanas \& Rautio, 2014) in the changing life circumstances. The second and third author took part in analyzing and theorizing the data, but were not involved in the field. The first author's relationships with the participants were intertwined and fluid throughout the research; the roles were constantly renegotiated with each arising situation (Lanas \& Rautio, 2014).

As a part of the broader hanging out, the first author conducted several audio-recorded in-depth interviews with the participants. This enabled hearing the stories of young asylum seekers as these unravel in the everyday life through the months and years, from moment to moment, as they live telling and re-telling their stories in different points in time. Interviewing rather than relying on the ethnographic hanging out was also an ethical choice; the first author was so intertwined in the participants' lives that she could no longer expect that her knowledge automatically constitutes data. In the interviews she could ask focused questions and the participants could answer these and assign which parts of their stories are data.

This article focuses on the stories of two men, Kokab and Mahammed, both of whom are still waiting for final decisions at the time of writing this article. Their stories were chosen for this paper because they were particularly thick in description and insightful regarding the themes of waiting and confinement. The stories have, however been told and read in the context of a broader in-depth research.

Interviews with Kokab and Mahammed were conducted twice: in the beginning of 2016 after they had lived in the temporary shelter for six months, and in 2018, after they had been waiting for a decision for three years and were living in rental apartments. At the end of the second interview, the first author read the transcripts of the first interview to the participants. This allowed the participants to mentally return to those moments, reflect on their thoughts, and consider what has changed, what feel the same and what they would like to add to their stories. All the participants were free to choose the places for the interviews - both Mahammed and Kokab chose the home of the first author. The interviews were conducted in English. They were thematic, loosely structured and open. This means that while there were some supporting questions (see Honkatukia, 2018, pp. 153-154), the participants were encouraged to talk about anything that felt important.

\section{Analysis}

The interviews were analysed in two stages. In the first stage the first author read and arranged the whole interview data by using NVivo. The purpose of this stage was to support us in understanding and addressing the data. In the second stage, Kokab's and Mahammed's interviews were analysed together by all authors by using narrative and post-structural tools, focussing on the situated and fluid 
experiences of young adult asylum seekers during the lengthy period of waiting. In this article, and in post-qualitative approaches in general, truths are seen as always partial and knowledge as always 'situated', as it is produced by and for particular interests, in particular circumstances and at particular times (MacLure, 2013). It is the situated, particular knowledge of asylum seeking young adults that this research is interested, and in order to do justice to this knowledge, we focus on two stories.

In what follows, we will first introduce Kokab and Mahammed, after which we will present and discuss the findings in the form of two individual stories. These stories are arranged according to the themes that were central in their interviews, conducted at two time points during their waiting (2016 and 2018). The stories were constructed through a slightly adapted form of narrative emplotment. Traditionally, emplotment refers to production of meaning in a story (Polkinghorne, 1995). However, instead of re-establishing significant relations between the participant's life events, we identified central themes related to confinement in the stories, and focused on what becomes addressed in the context of speaking about these themes. This way we may identify how confinement becomes described as Kokab and Mahammed tell about their lives. In the following section, we will portray the everyday lives as they are described by Kokab and Mahammed, and how confinement shows up in the stories. We complement this narrative by including dimensions from their past that appear particularly important for them.

\section{The participants}

The journeys of Kokab and Mahammed began in different parts of the world but overlapped in many ways after their arrival in Finland. Their time waiting in Finland featured the same cornerstones: their arrival alongside thousands of others in the fall of 2015, their settlement in the temporary shelter, their move to rental apartments and, most recently, their negative asylum decisions, against which they appealed. ${ }^{5}$

\section{Kokab}

Kokab grew up in two countries, Syria and Iraq. Even though he was used to moving a lot, he remembered those childhood places as something special: 'When you are in a different country than your country, the home for you is your pockets. But if I am in my country the home it's like my home. Like your parents, your brothers, your sisters' (Kokab, 2018).

Kokab often thinks back on his childhood in Syria, especially in regard to how he became the person he is now:

In the streets there is chairs and stuff. - - People come and talk, and I like to talk. We talk about many things in life, we talk about politics, religion, basic life, how the price is going up or down, or buses or something general in life. So we talk about everything. I grew up in that place. Every day I'm going there, talking, talk about bomb... Bomb, you know? And writing and meeting people. Now they are so important people, writing, and they are even in

\footnotetext{
${ }^{5}$ If an asylum application is rejected by the Finnish Immigration Service, the asylum seeker has the right to appeal to the Administrative Court. If the Administrative Court rejects the appeal, the asylum seeker can appeal to the Supreme Administrative Court.
} 
parliament so it's kind of a special place. But it's like just they sold tea and Hubble Bubble, they were smoking of course there. So that kind of... I like to talk. This is my kind of thing. So I miss that. (Kokab, 2018)

Kokab talked very little about the reasons for his escape, but it became clear that he was afraid: 'Culture religion, politics - - I am afraid of many things' (Kokab, 2016).

Kokab found a full-time job in a plastic factory ${ }^{6}$. Even though it is not his dream job, Kokab described being thankful to the company for hiring him, implying that asylum seekers are rarely employed. Keeping busy by working enabled Kokab to maintain a sense of moving forward and trying to focus on the present instead of the past:

But you know, like, busy life now. Especially for me, maybe if I am not busy, or maybe if I am at home or something, of course I will just like cry and miss everything in the past. But because I'm working, so this give me a way, like focusing not on the past things. (Kokab, 2018)

In both of Kokab's interviews, he apologized for talking too much. He said he likes talking with people, implying that it might have something to do with his profession: 'I write stories and poems. I was working before in a newspaper, talking about politics and religion’ (Kokab, 2016).

\section{Mahammed}

Mahammed came to Finland from Somalia. He had heard about Finland, but he was not sure 'if Finland was in Europe or if it was in North America' (Mahammed 2016). He expressed a desire to find work to fill his days. Mahammed's days proceed as follows: 'I wake up in the morning, I go to the gym, after the gym maybe I meet with my friends or go back to the house. I don't do anything more. Yeah, that is the normal life that I have.' (Mahammed, 2018)

Mahammed, like many young asylum seekers, misses his family in Somalia. He says that they are constantly on his mind:

Do you know when someone don't live with his family...-- You're leaving and you cannot go to see them, that's very difficult. That is the situation I am in, every day, that I think for my family and it's a bit difficult to stop that from my mind because I didn't see them for maybe quite a long time, and I don't know when I'm going to see them. So that's the situation I have here in this country. (Mahammed, 2018)

Mahammed said that he could have never imagined being forced to leave Somalia and seek for asylum from a place called Finland, or anywhere else:

When I used to live in my country life was good. I never thought that I'm gonna leave the country one day. I used to run my place, I owned this small shop. - - I used to have a friend called Abdi, but he's dead now, there in my place, in my own shop. - - When I told his family

\footnotetext{
${ }^{6}$ Asylum seekers are allowed to work after three months of their arrival, if they have presented a valid passport or other travel document - if not, they can start working after six month.
} 
that he had been killed by the troops of the government, and they [the troops] told me maybe they're gonna kill me, that's when life started to become difficult. (Mahammed, 2018)

Mahammed expressed that waiting for an asylum decision in Finland is his only choice: 'The decision I made was that I will never go out of this country, while I'm still scared of what I have seen before [in Somalia]' (Mahammed, 2016). He mentioned his hope that he would not feel the need to leave in the future: 'And I hope Finland makes me feel like I can live in my home. But I didn't feel quite a bit now, so... But I hope I will feel that' (Mahammed, 2018).

\section{Findings}

Both Kokab's and Mahammed's journeys took them to Finland, and to the temporary shelter in Northern Finland. The time Kokab and Mahammed spent in Finland waiting for their asylum decisions can be divided into two parts: their life in the temporary shelter and their life in rental apartments. Their narratives included descriptions of four forms of confinement: being confined in the shelter, being confined in movement, being confined in numbers and being confined in waiting. In the following sections we describe these.

\section{Being confined in shelter}

The overall experience of the temporary shelter was a combination of safe community and punitive confinement. In the first interviews, when Kokab and Mahammed still lived in the shelter, they described this time as stressful, as they lived in close quarters with many people and had too little to do. However, when reflecting on their life at the shelter in 2018, two years after moving out, Kokab and Mahammed remembered the staff and volunteers as meaningful parts of their stay at the shelter. They said that they missed the people; for both Kokab and Mahammed, the shelter felt protective because of the relationships they made there. They described the shelter not only as a place of confinement but also as a community. The residents, workers and volunteers at the shelter built practices and routines together from scratch, and these shared routines and ways of living created a sense of normality. While living in one's own home is a good solution when one has work and social connections, Kokab and Mahammed feared that moving away from the shelter would increase their loneliness and social exclusion.

When I was in the shelter, it was different because there were people who took care of the people, yeah. There were people who stopped in peoples' rooms asking how they are feeling and what they're doing and how life treats them. Nowadays I don't see that thing. (Mahammed, 2018)

For Mahammed, the shelter represented an actual shelter, as it was a place of safety, protection and care. He felt that he was recognized, respected and socially included as a member of the group; he found a place in the shelter. He talked about the people there as if they were his family, and they viewed him in the same manner:

I feel like my life is important to people. When someone follows your life, asks you what you do today, what you did yesterday, what you do tomorrow. It makes you feel like you are kind 
of important person to people, especially the people who work in the camp, who are taking care of you every day, asking about your life, asking if you feel good. (Mahammed, 2016)

For Kokab, the shelter was a community where people faced difficult situations together and supported each other:

You can connect with another life. - - When you live with many people, you are not upset all the time. When you live alone, it makes everything hard. Any news, any things affect you. When you are together and people help each other, they always help me or I help them. (Kokab, 2016)

However, both Kokab and Mahammed described the physical feeling of confinement produced by the material surroundings and residents' liminal status, as strongly unpleasant: 'Sometimes when I go back to camp ${ }^{7}$, I feel like I'm in a cage, or in something bad' Kokab (2016) argued, when still living in the shelter. This description is similar to the way reception centres have been compared to prisons (e.g. O'Reilly, 2018; Vitus, 2010) or human storages in which refugees may not have a right to live, but at least they have 'a right not to die' (Hyndman \& Giles, 2011, p. 362). In such places, people tend to have a lot of empty time and no possibility for privacy. In the shelter, big rooms were shared with other residents (up to 25 people per room), and the only private space was a bed or mattress on the floor. While these reception centres aim to protect and provide care, their confinement may feel punitive. Unlike people who are confined because of their crimes, asylum seekers are unaware of how long their waiting will continue (e.g. Kohli \& Kaukko, 2018): 'I didn't know I would be waiting for a long time. I had no idea it's gonna take this long to process' (Mahammed, 2018). This added to the perceived punitiveness of Mahammed's and Kokab's confinement.

\section{Being confined in movement}

Asylum seekers are on one hand confined in immobility, since while waiting for a decision they are unable to move freely between countries. On the other hand, they are confined to mobility, since they can be forced to relocate inside the country on a short term notice. The closing of the shelter in which the participants of this study lived suddenly scattered the residents across Finland to live in other centres. This showed them that forced movement was not over once they had reached a shelter, but they could be made move again at any time. If the residents wished to stay in the city they were in, as many did, they had to find a rental apartment from a private market. Not many private landlords are willing to rent their apartments to asylum seekers, so many of those leaving the shelter ended up living in apartments nobody else wanted and paying higher rent because of their lack of choice.

Mahammed sublet an apartment with a person he did not know. He struggled with not having a space or piece of furniture that is his own. In the shelter, he had his bed and that was enough: 'There was your own things, you lived in your place, you had your own bed, so... But when you live in someone's place that you can't understand so you can't live the way you want' (Mahammed, 2018). Mahammed said he preferred the shelter over his current living conditions, and he mentioned that while he missed the feeling of togetherness in the shelter, he was also afraid to reside at the reception centre because he might be sent to another city:

\footnotetext{
${ }^{7}$ In spoken language, 'camp' often refers to all kinds of asylum centres. In this research it refers to the shelter.
} 
Mahammed (2018): Yeah, there is the reception centre, I can live there maybe, but I think if I say that I don't have place to live and I wanna live in a camp, maybe they're gonna transfer me to another place.

Maria: Some other city?

Mahammed: Yeah, some other city. That's what I'm scared of, to get transferred to another place.

For Mahammed, the shelter was a convenient place to stay. He did not rule out the possibility of living in such a place again, as long as he could keep his chosen mobility.

Kokab argued that life was generally better in rental apartments compared to shelters because he could choose who to live with. Kokab described many of the residents' experiences at rental apartments as follows: 'They go to big apartment and they live together so it's like small camps' (Kokab, 2018). His own life was structured around his work in a plastic factory, that gave him a sense of control of his own time and movement, including the rhythm and pace that kept him moving onward in his everyday life:

When I wake up. First thing I open my eyes and I see the roof and then stand, so tired, and then go to bathroom and wash everything, get ready, get food from fridge. Sometimes I bought it before one day and sometimes I make it so fast. But usually I bought one week's food ready for the next week. So, take my bag, wear my clothes and go waiting in the snow in the bus stop and then the bus will come and take me to the work. And yeah, what else. Start working. Or before that I make, if I'm early, coffee, and then start working. We have many tauko [breaks], I work eight hours, then come back from work at four o' clock. - - Then watch TV, I have show now, it's called How I Met Your Mother. (Kokab, 2018)

Employment alleviates some of the challenges, as Kokab (2018) described: 'Of course when I have my room, my things, my stuff, so it's better for me'. A salary enables one to have more control over one's own movement, it enables one to live alone or with only a few people. Having a place of one's own also includes the possibility — and, for some, the ethical pressure — of helping those who lack a home, including friends who are facing the threat of detention or enforced deportation and are in hiding. The lack of access to support structures pushes these asylum seekers into further (forced) mobility, as they need to find new ways to secure their basic needs.

It's a bit difficult, it's not maybe safe because everything became too difficult because we used to live in the shelter and you didn't worry about the place that you were sleeping. Guys now live in houses and they rent houses and some of them work and some of them don't and some of them has maybe four or five negatives and they don't get any benefits ${ }^{8}$ from the camp or anything so... Yeah, life is difficult and people are stressed out, so much. (Mahammed, 2018)

The stories of Kokab and Mahammed portray in an interesting way how an asylum seeker's control of their own movement depends on the phase of their asylum process. Whereas a positive asylum

\footnotetext{
${ }^{8}$ Over 18 year-old asylum seeker, living outside of a reception centre receives $263,78 \mathrm{e}$ of monthly reception allowance. If the asylum seeker has received a decision on deportation, s/he can no longer stay at the reception centre and will no longer receive a reception allowance or other services offered by the reception centre, such as health care. (Finnish Immigration Service 2019)
} 
decision grants them permission to stay in one place at least for as long as the residency permit is valid, deportation decision throws them into further involuntary movement: removal back to the country of origin or couch surfing to escape deportation. During the waiting process they can increase their control of their own movement by securing societal 'anchors' (see also Verdasco, 2018), such as employment or an apartment.

\section{Being confined in numbers}

Social othering is common in the everyday lives of asylum seekers in the form of degrading treatment, discrimination and preconception. The dehumanising effect of such othering was intensified by the experience of being confined in numbers. The experience appeared in the stories in two ways: numbers defined not only the individual's life prospects, but also the individuals themselves.

Asylum seekers are aware of their position in social hierarchies, as Mahammed (2016) noted at the beginning of the first interview: 'I cannot do anything at the moment. I'm like, you know, I'm an asylum seeker who lives in a camp'. In saying so, he referred to the restrictions on his everyday decision-making possibilities and his limited mobility when he was living in the shelter. Also, for him and many others, 'an asylum seeker who lives in a camp' is the lowest possible status. Mahammed (2018) talked about how he was used to experiencing racism; it was just a part of his life, and he accepted it because 'that's what happens in every country'. These kinds of positions and perceptions about oneself are amplified by the structural othering of the immigration system:

Then she [an immigration official] told me, 'I'm sorry, that's the truth, in Immigration Office you are a number: we delete the number, we put the number, we give the appointment for the number, not for the person'. So this kind of things hurt me. --If you feel like you are nothing. Or just like you are a number. (Kokab, 2018)

Kokab wanted to fight this positioning by trying to show Finnish people that asylum seekers 'are human too'. Just a few months after arriving in Finland, he started to volunteer. He said he wanted to give something back to the host society, build a common ground with Finnish citizens and diminish the gap between 'us' and 'them'. In the first interview, he described the purpose of volunteering:

It's important to like... Some families here are racist or something and we should like show

how we behave and how we... Something we share, we play football there and they play football here, it's like... We are human too. (Kokab, 2016)

Numbers state the asylum seekers life prospects. In the stories, the amount of negative asylum decisions states in a numeric form the amount of hope they have. Someone with no decisions has much hope, whereas someone with three decisions has little hope. It can be seen as something that allows the two types of time, everyday time and future time, to interact (Brun 2015), and for many, the number of denied applications represents the direction of their future. Mahammed's application has been rejected twice.

It makes you feel like you don't wanna live anymore. - - It makes you think that they give you a negative decision because they don't want you. They want you to leave the country. So, you do that. It makes you think a lot. But it's okay. If you're a strong person, then maybe you can come over all this. (Mahammed, 2018) 
Kokab analogized his three negative asylum decisions to nails in his coffin. After each decision, his future slipped further away from him until he finally stopped believing in a future in Finland. He feared for his future, as he had witnessed what has happened to his friends in similar situations:

But now, I don't think about future because there is no future here. But of course I am living my life normal, but somehow without hope, without meaning. I'm working and get salary, but without meaning because I know someday in this year I will stop everything. (Kokab, 2018)

'I will stop everything' refers to what will happen if he gets deported from Finland: his work, relationships and all normality he has managed to build in his life will be wiped out. Until then, he planned to live his life as normally as possible, despite his gloomy future.

\section{Being confined in waiting}

According to the stories of Kokab and Mahammed told in two different points in time, prolonged waiting may be experienced as confining. This confinement in waiting becomes a part of one's existence and eventually also even part of the person.

At the beginning of the young men's stay at the shelter, the atmosphere was mostly hopeful: 'And my first days I was so excited and I was so happy and I was trying and I was building something very beautiful' (Mahammed, 2018). Negative decisions had not been received yet, and many thought of a better future. In this moment after arrival they were in a liminal stage, neither citizens of the present nor the past (Malkki 1997, p. 63), and they felt the 'freedom of in-betweenness' (Ghorashi Boer \& Holder, 2017). However, as time went by and things changed, but not in the desired direction, the inbetweenness started to feel less like freedom and more like confining. As the liminal stage continued infinitely, the freedom Mahammed had experienced before started to fade away. It turned into an internalized sense of being a liminal being (O'Reilly, 2018), as Mahammed describes. The waiting changed him as a person:

I used to be a happy person who laughs every time and who makes other people happy but from the day I came here there is a lot of things change in myself because I'm not like before, at all. I feel that I have changed a lot. (Mahammed, 2018)

Prolonged time of waiting accumulates into one meaningless event after another, and life may feel worthless and empty (Kohli, 2014). Boredom becomes a symbol of waiting and represents being stuck in an eternal present. Jefferson, Turner and Jensen (2019) propose the term 'stuckness' to refer to the way confinement is experienced, sensed and lived; the experience of stuckness is not simply an expression of physical confinement and spatial closure but expresses the way people make sense of confining dynamics and practices. Time seems to slow down (e.g. Bengtsson, 2012, Kaukko \& Parkkila, 2014; Kohli \& Kaukko, 2018). The feeling of wasting one's life waiting intensifies. As Mahammed (2018) said: 'You are waiting a lot of time and the time is running and there is nothing going to happen'.

After three years of waiting Kokab was no longer sure what he was waiting for: 'Yeah, waiting for nothing. I arrive to place, I'm waiting for nothing. So I didn't expect that. I give patience to wait one year, it's okay, one and half years, then two years. Then we are like going to three years. And nothing' 
(Kokab, 2018). This view is in stark contradiction to the optimism he had when he began to wait. Time has turned from a promise to a threat (Jefferson \& Segal, 2019).

When Kokab arrived in Finland at the end of summer 2015, less than 10 percent of Iraqis applying for asylum received a negative decision. The next year, when Kokab applied, 80 percent of all applicants received negative decisions (Finnish Immigration Service, 2019). Like other European Union countries, Finland had tightened its asylum policies not because the situation in Iraq would be significantly safer for asylum seekers, but because so many had fled to safety. For Kokab, and many other asylum seekers, this felt unfair:

And the Immigration Office, they didn't... They closed the doors. And even I know many people, they get married, they have children. Immigration Office give them rejection. So what in the hell they want? If you have a family here, they reject you. If you are working, they reject you. If you want asylum, they reject you, so what they want exactly? We don't know. (Kokab, 2018)

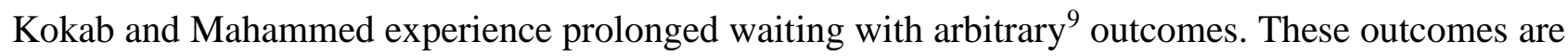
not related to the situation in their country of origin or their own actions, and as they wait, they feel deprived of any control over their own destinies. They are youth confined in an eternal present, and planning for life loses meaning: 'Before I was planning my future. But now I don't believe in planning' (Kokab, 2018).

\section{Conclusions}

Young adults are at a stage of their lives when they want to take responsibility, gain independence and start their own lives. Kokab's and Mahammed's stories show how their initial sense of freedom upon arrival turned into sense of stuckness, as they, like many other young asylum seekers became confined in the Finnish society: they experienced being confined in waiting, in numbers, in movement and in shelter. It is notable that of these dimensions of confinement, the shelter also included distinctive positive aspects. While the invisible and abstract forms of confinement - forced movement, indefinite waiting, and being turned into a number - appeared as imprisoning and agonising, the concrete confinement in the shelter, perhaps surprisingly, consisted of safe and comforting aspects.

Being simultaneously confined in movement and in waiting means that people are kept on hold, but they are expected to be ready to move (Thorshaug, 2018). Individuals navigate and negotiate this undoubtedly precarious position in various ways. For both Kokab and Mahammed, the decision of renting an apartment served as a buffer against the uncertainties - it stopped them from being moved around. However, it also left them more alone in everyday and, especially in Mahammed's case where there was no work, short of money.

Kokab's and Mahammed's stories show how asylum seekers' political condition confines them into a status similar to that of a minor, awaiting a permission to begin their lives as recognised members of society. Their stories imply of the ways in which restrictive immigration policies and institutionalized othering become normalised (for example, Kokab's encounter with the immigration

\footnotetext{
${ }^{9}$ For example, over 60 changes to the Aliens Act (301/2004) were made by the end of the year 2015 (Välimäki, 2019).
} 
official, which turned out to be a missed opportunity to encounter, see and listen Kokab as a human), while structural inequalities (based on class, race, ethnicity, gender, religion, etc.) are attributed to 'individual' failure rather than the material and relational work of pre-existing and historicised power relations (Green, 2019; De Lissovoy, 2012). In other words, asylum processes seemingly evaluate the situations of the individual and their countries of origin, while in reality, these situations have little impact on the asylum outcome.

Combined, confinement in waiting, in numbers, in movement and in shelter all limit the possibilities for agency. However, while asylum seekers can do little about their confining situations, Kokab's and Mahammed's stories show that they can still create various forms of engagement in the communities in which they live. They found small pockets of escape from various forms of confinement: they negotiated their own humanity through volunteering, they turned a physically confining shelter into a warm experience, they gained some level of control over their movement by achieving societal anchors (apartment, work), and by doing these they also lessened the passivity of waiting helplessly. The close relationships between staff, residents and volunteers at the shelter were developed while establishing practices and routines to enable harmonious co-living inside. These temporal attachments were vital in alleviating the experience of confinement. As time went by, the temporal attachments developed into reciprocal, meaningful relationships that still last, even after the people of the community have scattered and the material surroundings have been taken down. In this way, the experience of confinement also involved love, care and recognition. 'Now still like, even if I live alone, I have people from the camp and I know them. If I need help they will help me, if they need help I will help them, always.' (Kokab, 2018).

\section{References}

Abourahme, N. (2014). Assembling and spilling-over: Towards an "ethnography of cement" in a Palestinian refugee camp. International Journal of Urban and Regional Research, 39(2), 200-217.

Allsopp, J., Chase, E. and Mitchell, M. (2015). 'The Tactics of Time and Status: Young People's Experiences of Building Futures While Subject to Immigration Control in Britain'. Journal of Refugee Studies 28(2): 163-182.

Agamben, (1998). Homo sacer. Stanford, CA: Stanford University Press.

Bailey, A. J., Wright R. A., Mountz, A., \& Miyares I. M. (2002). (Re)producing Salvadoran transnational geographies. Annals of the Association of American Geographers, 92(1), 125-144.

Bengtsson, T. T. (2012). Boredom and action-experiences from youth confinement. Journal of Contemporary Ethnography, 41(5), 526-553.

Brun, C. (2015). Active waiting and changing hopes: Toward a time perspective on protracted displacement. Social Analysis, 59(1), 19-37.

Campesi, G. (2015). Humanitarian confinement: an ethnography of reception centres for asylum seekers at Europe's southern border. Migration and Border Studies, 1(4), 398-418.

Chase, E. (2013). Security and subjective wellbeing: the experiences of unaccompanied young people seeking asylum in the UK. Sociology of Health \& Illness, 35(6), 858-872.

Cole, D. R. (2013). Lost in data space: Using nomadic analysis to perform social science. In R. Coleman \& J. Ringrose (Eds.), Deleuze and research methodologies (pp. 219-237). Edinburgh: Edinburgh University Press. 
De Lissovoy, N. (2012). 'Conceptualizing the carceral turn: Neoliberalism, racism and violation', Critical Sociology, 39(2), 739-55.

Duncombe, J. \& Jessop, J. (2002). 'Doing rapport' and the ethics of 'Faking Friendship'. In M. Mauther (Eds.), Ethics in qualitative research. (pp. 107-122). London: SAGE.

Enell, S. (2017). 'I Got to Know Myself Better, My Failings and Faults': Young People's Understandings of being Assessed in Secure Accommodation. YOUNG, 25(2), 124-140.

Finnish Immigration Service. (2019). Statistics: International Protection. Retrieved from: http://tilastot.migri.fi/\#applications/23330?1=en\&start=540\&end=551

Finnish Immigration Service. (2019). Reception allowance. Retrieved from: https://migri.fi/en/receptionallowance

Fontanari, E. (2015). Confined to the threshold: The experiences of asylum seekers in Germany. City, 19(5), $715-726$.

Ghorashi, H., Boer, M., \& Holder, F. (2017). Unexpected agency on the threshold: Asylum seekers narrating from an asylum seeker centre. Current Sociology, 66(3), 373-391.

Green, B. (2019). Drowning In Neoliberal Lies: State Responses Towards People Seeking Asylum. British Journal of Social Work (2019)0, 1-18.

Heyl, B.S. (2007). Ethnographic interviewing. In P. Atkinson (Eds.), Handbook of ethnography. London: SAGE Publications.

Honkasalo, V., Maiche, K., Onodera, H., Peltola, M. \& Suurpää, L. (2017). Young People at Reception Centres. Helsinki: Finnish Youth Research Society, Finnish Youth Research Network.

Honkatukia, P. (2018). Haastattelu nuorisotutkimuksen metodina. [Interview as a method in youth research] In T. Kiilakoski \& P. Honkatukia (Eds.), Miten tutkia nuoria ja nuorisotyötä? (pp. 149-170). Tampere, Finland: Vastapaino.

Hyndman, J., \& Giles, W. (2011). Waiting for what? The feminization of asylum in protracted situations. Gender, Place \& Culture: A Journal of Feminist Geography, 18(3), 361-379.

Ikävalko, E. (2016). Vaikenemisia ja vastavirtaa. Valtasuhteet ja toiminnan mahdollisuudet oppilaitosten tasaarvosuunnittelussa. (Doctoral dissertation, University of Helsinki).

Jefferson, A. \& Segal, L. (2019). The Confines of Time - On the Ebbing Away of Futures in Sierra Leone and Palestine, Ethnos, 84(1), 96-112.

Jefferson, A., Turner, S. \& Jensen, S. (2019). Introduction: On Stuckness and Sites of Confinement, Ethnos, 84(1), 1-13.

Kaukko, M. Korkiamäki. R. \& Kuusisto, AK (2019). Normatiivisesta etiikasta elettyyn kohtaamiseen: tutkimuksellista hengailua yksin tulleiden maahanmuuttajanuorten kanssa. In Kaisa Vehkalahti \& Niina Rutanen (Eds.) Lasten ja nuorten tutkimuksen etiikka II. Helsinki: Youth Research Network.

Kaukko, M. \& Parkkila, H. (2014). Nykyajan totaaliset laitokset tyttöjen suojelijoina. In Gissler, Kekkonen, Känkäinen, Muranen \& Wrede-Jäntti (eds.) Nuoruus toisin sanoen. Helsinki: Youth Research Network and National Institute for Health and Welfare, 113-121.

Kohli, R. K. S. (2014). Protecting asylum seeking children on the move. Revue Européenne des Migrations Internationales, 30(1), 83-104.

Kohli, R., \& Kaukko, M. (2018). The management of time and waiting of unaccompanied asylum seeking girls in Finland. Journal of Refugee Studies, 31(4), 488-506.

Koser, K. (Ed.). (2016). Unaccompanied Minors Virtual Issue. [Special issue] Journal of Refugee Studies. Retrieved from: https://academic.oup.com/jrs/pages/virtual_issue_unaccompanied_minors 
Lanas, M. \& Rautio, P. (2014). Reciprocity as relational. Two examples of conducting research in Finnish Lapland. In S. White \& M. Corbett (Eds.), Doing Educational Research in Rural Settings. Methodological issues, international perspectives and practical solutions. London: Routledge.

Lems, A., Oester, K. \& Strasser, S. (Eds.). (2019). Children of the crisis: ethnographic perspectives on unaccompanied refugee youth in and en route to Europe. [Special issue] Journal of Ethnic and Migration Studies, DOI: 10.1080/1369183X.2019.1584697

Malkki L. (1995) Refugees and exile: From "refugee studies" to the national order of things. Annual Review of Anthropology, 24(1), 495-523.

Malkki, L. (1997). National geographic: The rooting of people and the territorialization of national identity among scholars and refugees. In A. Gupta \& J. Ferguson (Eds.), Culture, power, place: Explorations in critical anthropology (pp. 52-74). Durham, NC, and London: Duke University Press.

MacLure, M. (2013). Classification or wonder? Coding as an analytic practice in qualitative research. In R. Coleman \& J. Ringrose (Eds.), Deleuze and research methodologies. Edinburgh: Edinburgh University Press.

Martin, L., \& Mitchelson, M. (2009). Geographies of detention and imprisonment: Interrogating spatial practices of confinement, discipline, law, and state power. Geography Compass, 3(1), 459-477.

Mountz, A. (2011). Where asylum seekers wait: Feminist counter-topographies of sites between states. Gender, Place and Culture, 18(3), 381-399.

Mountz, A., Coddington, K., Tina Catania, R., \& Loyd, J. M. (2013). Conceptualizing detention: Mobility, containment, bordering, and exclusion. Progress in Human Geography, 37(4), 522-541.

Murphy E., \& Dingwall R. (2007). The ethics of ethnography. In P. Atkinson (Eds.), Handbook of ethnography. London: SAGE Publications.

Nykänen, T., Koikkalainen, S., Seppälä, T, Mikkonen, E., \& Rainio, M. (2019) Poikkeusajan tilat: vastaanottokeskukset pohjoisessa Suomessa. [Spaces in times of exception: Reception centres in Northern Finland] In E. Lyytinen (Eds.), Turvapaikanhaku ja pakolaisuus Suomessa. (pp. 161-184). Turku, Finland: Siirtolaisinstituutti.

O'Reilly, Z. (2018). 'Living Liminality': Everyday experiences of asylum seekers in the 'Direct Provision' system in Ireland. Gender, Place \& Culture, 25(6), 821-842.

Oxford Dictionaries. (2019). Definition of confine in English. Retrieved from: https://en.oxforddictionaries.com/definition/confine

Perre, N., De Vries, M., Richards, H., \& Gkliati, M. (2018). Refugee crisis: Three perspectives on the makings of a crisis. Retrieved from https://rli.blogs.sas.ac.uk/2018/04/16/refugee-crisis-three-perspectives-on-themakings-of-a-crisis/

Petäjäniemi, M., Lanas, M., \& Kaukko, M. (2018). Osallisuus turvaa hakevan reunaehdoissa: hätämajoitusyksikössä asuvien nuorten turvapaikanhakijamiesten kertomuksia arjesta. [Participation as part of the boundary conditions of an asylum seeker: Stories of participation, inclusion and exclusion of young male asylum seekers living in a temporary shelter] Aikuiskasvatus 38(1), 4-17.

Polkinghorne, D. E. (1995). Narrative configuration in qualitative analysis. International Journal of Qualitative Studies in Education, 8(1), 12-28.

Pyyry, N. (2015). Hanging out with young people, urban spaces and ideas: Openings to dwelling, participation and thinking. (Doctoral dissertation, University of Helsinki).

Rotter, R. (2016). Waiting in the asylum determination process: Just an empty interlude? Time \& Society, 25(1), 80-101.

Schweizer, H. (2008). On waiting (thinking in action). London: Routledge. 
Sharma, S. (2008). Baring life and lifestyle in the non-place. Cultural Studies, 23(1), 129-148.

Sigona, N. (2015). Campzenship: Reimagining the camp as a social and political space. Citizenship Studies, 19(1), 1-15.

Stacey J. (1988). Can there be a feminist ethnography? Women's Studies International Forum 12: 579-592.

Tani, S. (2014). The Right to be Seen, the Right to be Shown: Ethical Issues Regarding the Geographies of Hanging Out. YOUNG, 22(4), 361-379.

Thorshaug, R. (2018). Arrival in-between: Analyzing the lived experiences of different forms of accommodation for asylum seekers in Norway. In B. Meeus, K. Arnaut, \& B. van Heur (Eds.), Infrastructures: Migration and urban social mobilities (pp. 207-227). [Place of publication not identified]: Palgrave Macmillan.

Turner V. (1964). Betwixt and between: The liminal period in Rites de Passage. The proceedings of the American Ethnological Society. Symposium on the new approaches to the study of religion: 4-20.

United Nations High Commissioner for Refugees. (2018). Figures at a glance: Statistical yearbooks. Retrieved from http://www.unhcr.org/en-au/figures-at-a-glance.html

Verdasco, A. (2018). Communities of belonging in the temporariness of the Danish Asylum System: Shalini's anchoring points. Journal of Ethnic and Migration Studies, 45(9), 1-19.

Verdasco, A. (2019). Everyday Rituals of Migration: Constructing Relatedness and Agency among Young Refugees in Denmark. Ethnos, DOI: https://doi.org/10.1080/00141844.2019.1604558

Vitus, K. (2010). Waiting time: The de-subjectification of children in Danish asylum centres. Childhood, 17(1), $26-42$.

Välimäki, M. (2019). Kylmän sodan ajasta eurooppalaiseen päätöksen-tekoon: kansainvälistä suojelua hakevia ihmisiä koskeva politiikka ja lainsäädäntö 1973-2015. [From the time of Cold War to European decision making: the politics and law regarding people seeking international protection] In E. Lyytinen (Ed.), Turvapaikanhaku ja pakolaisuus Suomessa (pp. 161-184). Turku, Finland: Siirtolaisinstituutti.

Yle. (2018). Turvapaikkahakemukset käsiteltävä kohta puolessa vuodessa [Asylum applications need to soon be processed in six months.] https://yle.fi/uutiset/3-10204654 